\title{
Storage Stability of Fish Oil from Langkawi Island, Malaysia
}

\author{
Irwandi JASwIR $^{1 *}$, Farida OSMAN ${ }^{2}$, Alfi KHATIB ${ }^{3}$ and Ahmed Jalal Khan CHOWDHURY ${ }^{2}$ \\ ${ }^{1}$ Department of Biotechnology Engineering, Faculty of Engineering, International Islamic University Malaysia, Jalan Gombak, 53100 \\ Kuala Lumpur, Malaysia \\ ${ }^{2}$ Faculty of Science, International Islamic University Malaysia, P.O Box 141, Kuantan, 25710, Pahang Darul Makmur, Malaysia \\ ${ }^{3}$ Department of Food Science, Faculty of Food Science and Technology, Universiti Putra Malaysia, 43400 Serdang, Selangor, Malaysia
}

Received April 22, 2008; Accepted July 22, 2009

Fish oils extracted from 6 species of marine fin fish caught from Pulau Tuba area, near Langkawi Island, a famous tourism destination in Malaysia, were evaluated for their oxidative stability during storage at both -27 and $4^{\circ} \mathrm{C}$. The five fish species were "kerisi" (threadfin breams,sScomberomorus commersoni), "kerapu" (groupers, Cynoglossus lingua), "kembong” (Indian mackerel, Psettodes crumei), "gelama kling" (drum-croaker-jewfish, Pristipomodes typus), and "tinggiri batang" (Spanish mackerels, Scolidon sorrakowah). Results showed that stability of oils stored at $-27^{\circ} \mathrm{C}$ was better than that of oils stored at $4^{\circ} \mathrm{C}$. Iodine value (IV) of oils decreased during storage, while other parameters, namely peroxide value (PV), anisidine value (AnV), acid value (AV) and thiobarbituric acid (TBA) value increased. However, the rate of quality deterioration of oil samples was relatively low, as shown by very little changes in fatty acid profiles of the oil, meaning that both storage temperatures might be used for storage purposes of fish oil.

Keywords: fish oil, marine sources, storage stability, Malaysia

\section{Introduction}

Fish oil has been around for a very long time (Marchioli, 2001). It has become more popular because of its useful effects on human health. Current research studies indicated the importance of fatty acids of fish flesh for human health due to its high proportion of unsaturated fatty acid esters.

Fish lipids are well known to be rich in long chain n-3 polyunsaturated fatty acid (PUFA), especially eicosapentaenoic acid (EPA) and docosahexaenoic acid (DHA). These fatty acids play a vital role in human nutrition, disease prevention, and health promotion (Rafflenbeul, 2001). Besides, arachidonic acid (AA) and DHA are structural components of cell membrane phospholipids and precursors of eicosanoids, which play important roles in the development of the central nervous system including the retina. Moreover, many studies have shown that fish oil supplementation increases the DHA content of blood components (Connor, 2000).

Fish oil also has important industrial applications in food, pharmacy, cosmetics, and paint products. However, due to its high content of polyunsaturated fatty acids, including EPA

*To whom correspondence should be addressed. E-mail: irwandi@iiu.edu.my and DHA, fish oil is normally highly susceptible to oxidative spoilage (Huss, 1988) and the rate of fish oil oxidation is significantly different from that of other oils.

In the food system, the application of fish oils has a limitation because lipids are labile when exposed to heat, air and light. Also, the unpleasant taste and odor of fish oil can cause deterioration in the quality of food products (Huss, 1988). The measure of lipid oxidative stability therefore, is an important task because this determines the shelf-life of many foods. Foods having low oxidative stability degrade quickly, producing undesirable flavors and unhealthy compounds. This property is especially significant in foods containing high proportions of unsaturated acyl groups, such as in fish (Huss, 1988).

The objective of this study was to investigate the stability of fish oil produced from marine fin fish caught in Pulau Tuba area, near Langkawi Island, a major tourist resort in Malaysia during storage at -27 and $-4^{\circ} \mathrm{C}$. The five fish species studied were selected because they have quite considerable commercial importance in Malaysia.

\section{Materials and Methods}

Fish species and chemicals Fish oil, extracted from 
marine fin fish caught from Pulau Tuba area, near Langkawi Island on 15 October 2004 was used in this study. Six fish species commonly found in the island, namely "kerapu" (groupers, Cynoglossus lingua), "kembong” (Indian mackerel, Psettodes crumei), "kerisi” (threadfin breams, Scomberomorus commersoni), "gelama kling" (drum-croakerjewfish, Pristipomodes typus), and "tinggiri batang" (Spanish mackerels, Scolidon sorrakowah) were selected to be used in this study.

All chemicals used were of analytical grade and obtained from Merck (Germany) and Sigma-Aldrich (USA).

Sample preparation Fish samples were washed with clean sea water at the point of collection, separated by species, packed in plastic bags and transferred to the laboratory under ice boxed where they were kept at $-27^{\circ} \mathrm{C}$ until analyzed.

Prior to extraction of the oil the fish was thawed at $4^{\circ} \mathrm{C}$ for 12 hours and duplicated samples of each type of fish were obtained from eviscerated fish consisting of flesh and skin. The fish lipids were extracted by Folch (1957) method with slight modifications. The fish samples were homogenized with a mixture of chloroform and methanol $(2: 1, \mathrm{v} / \mathrm{v})$. Sodium chloride solution $(0.9 \%, \mathrm{NaCl})$ were added to the homogenate and centrifuged at $3000 \mathrm{rpm}$ for $15 \mathrm{~min}$ at $4^{\circ} \mathrm{C}$ after vortex three times for $30 \mathrm{~s}$. The lower clear phase were collected and concentrated with a rotary evaporator at $35^{\circ} \mathrm{C}$. The concentrated lipid extract was quantitatively transferred to a vial. Aliquots were evaporated to constant weight under nitrogen to determine total lipid content.

Analysis of antioxidant activity of fish oil Antioxidant activity originally present in the fish oil was determined by oxygen consumption measurement method. This analysis was conducted to determine whether the fish oil contain initial antioxidants which might contribute to the extended shelf-life of the oil. Oxygen depletion in a linoleic acid emulsion system with added ferrous $\left(\mathrm{Fe}^{2+}\right)$ ions, and in the absence and presence of the fish oil, was measured according to the methods of McGookin and Augustin (1991), Lingnert et al., (1979), and Wijewickreme and Kitts (1997) using a YSI Model 5300 biological oxygen monitor (Yellow Springs, $\mathrm{OH})$. Each sample of the fish oil were first dissolved in a linoleic acid emulsion (1.5 g of linoleic acid mixed with $0.1 \mathrm{~g}$ of Tween 20 in $40 \mathrm{~mL}$ of $0.1 \mathrm{M}$ potassium phosphate buffer ( $\mathrm{pH}$ 6.8)). One milliliter of this mixture was then mixed with $5 \mathrm{~mL}$ of buffer (0.1 M potassium phosphate buffer, $\mathrm{pH} 6.8$ ), and $0.6 \mathrm{~mL}$ of $2 \mathrm{mM} \mathrm{FeSO}_{4}$ dissolved in $0.1 \mathrm{M}$ potassium phosphate buffer ( $\mathrm{pH}$ 6.8). The reaction mixture was pumped into a jacketed reaction vessel containing an oxygen electrode at room temperature. Oxygen depletion was recorded immediately after the reaction mixture was introduced into the vessel. Both antioxidant and prooxidant activity of natural antioxidant mixtures were expressed in terms of protective index (PI), defined as:

$$
\mathrm{PI}=\frac{\text { time for } 50 \% \mathrm{O}_{2} \text { depletion with test compound }}{\text { time for } 50 \% \mathrm{O}_{2} \text { depletion without test compound }}
$$

where PI $<1$ denotes prooxidant activity, $\mathrm{PI}=1$ denotes no activity, and $\mathrm{PI}>1$ denotes antioxidant activity (Lingnert et al., 1979).

A $50 \% \mathrm{O}_{2}$ depletion is reached when the oxygen concentration left in the chamber is half $(50 \%)$ from the initial concentration.

Fatty acid analysis Fatty acids contents of the total lipid extracted were determined by methlylation of $0.1 \mathrm{~g}$ of lipid with $1 \%$ sulphuric acid-methanol at $95^{\circ} \mathrm{C}$ for $2 \mathrm{~h}$. The lipid samples were placed in a test tube then $1 \mathrm{~mL}$ of toluene and $1 \mathrm{~mL}$ of the sulphuric acid-methanol were added and the mixtures were heated for $2 \mathrm{~h}$ at $95^{\circ} \mathrm{C}$. After cooling the samples under ice, $1 \mathrm{~mL}$ of water and hexane were added and the samples were vortexed and centrifuged. The methylated fatty acids were collected under hexane and evaporated by nitrogen gas and then reconstitute with hexane before running for gas chromatography (GC) for fatty acid analysis.

Routine analyses of fatty acid methyl esters (FAMEs) were performed by a Perkin Elmer gas cromatography-mass spectrometer (GC-MS) Model Autosystem XL equipped with FID detector where hydrogen and compressed air were used. A capillary column $(30 \mathrm{~m} \times$ diameter $0.25 \mu \mathrm{m}$ film thickness) with split ratio of 50:1 was used to separate the esters. Hexane was used as a liquid phase for the sample. The analyses were performed at initial temperature of $160^{\circ} \mathrm{C}$ for 5 minutes and raised to $250^{\circ} \mathrm{C}$ for $10 \mathrm{~min}$ at a rate of $4^{\circ} \mathrm{C} / \mathrm{min}$. Temperature of injector and detector was $280^{\circ} \mathrm{C}$. Helium gas was used as carrier gas flowing at $1 \mathrm{~mL} / \mathrm{min}$. The fatty acids compositions of the sample and fish oil were identified by comparison with retention times of known standard mixture (Sigma Chem. Co.) of fatty acids. Menhaden oil (Sigma Chem. Co.) was used as standard PUFA.

$I V, P V, A n V, A V$ and TBA analyses Iodine value (IV), peroxide values (PV), and anisidine value (AnV), acid value (AV) and thiobarbtituric acid (TBA) value were used to measure the extent of lipid oxidation. These determinations were carried in triplicate during storage. PORIM test methods (1995) were used to determine PV, IV, TBA, and AV while AnV was determined according to IUPAC methods (1987).

Statistical analysis All data were evaluated with statistical analysis system software (SAS, 1989). This program was used to analize data for determining analysis of variance (ANOVA), standard deviation and Tuckey's multiple range test (Steel and Torrie, 1980). In all tables, statistical signifi- 
cance is indicated by appropriate letters within the tables.

\section{Results and Discussion}

Assessment of antioxidant activity by oxygen consumption measurement In this study, oxygen consumption measurements were undertaken as a chemical measure for evaluating lipid oxidation reactions. The percentage of oxygen remaining in the reaction chamber over a period of time, in the absence and presence of antioxidant- contained fish oil, was recorded as a measure of calculating PI values of these antioxidants. Figure 1 shows percentage oxygen consumption by the fish oil, as well as rosemary extract for comparison, in a linoleic emulsion system.

It is clear that the percentage of oxygen remaining in the vessel depleted more rapidly in the control emulsion compared to the other emulsions containing the fish oil samples. It indicated that no fish oil sample with a potential prooxidant activity was observed.

All samples, including control, initially contained 22\% remaining oxygen in the chamber. For calculating the PI values, the indicator used was the duration (in minutes) needed to reach $11 \%$ (i.e, half or $50 \%$ of initial value, $22 \%$ ). For the control, sample it was required $20 \mathrm{~min}$ to reach $11 \%$ percent oxygen left in the chamber.

All types of fish oil evaluated were found to have the longer time to reach the $11 \%$ oxygen in left the chamber, with 27 to $28 \mathrm{~min}$, meaning that this sample had antioxidative activity. The antioxidative activities of these oils, however, were lower than those of rosemary extract. This commercial antioxidant was found to have $140 \mathrm{~min}$ time to reach the $11 \%$ oxygen in the chamber.

The PI values, employing an iron-suplemented linoleic model emulsion system in which iron ions act as a promoter of lipid oxidation reactions, are useful to distinguish between antioxidant and prooxidant activities of various mixture samples. From this study, results showed that for all the oil samples studied, the PI values calculated were higher than control $(=1)$. It indicated that the oils has initial capacities to act as antioxidants. The PI values of the oil were found to be between 1.35 ("kerapu") to 1.40 ("gelama kling", "tenggiri", and "kembung"). The PI value for "kerisi" oil was 1.39. Results also showed that there was no difference in antioxidative activity among the samples evaluated. However, the antioxidative capacity available in the fish oils were much lower than that of rosemary extract. The PI values of the rosemary extract was 7.0.

Fatty acid profiles of fin fish Detailed fatty acid compositions of fish oil in this study and their changes during storage are listed in Table 1. The compositions were determined at the end of storage period (i.e, after 3 weeks) and they were compared to that of fresh oil. The compositions were based on the total fats of fish body from three different parts (i.e. head, middle, and tail).

In general, fresh fish oil in this study consisted of saturated fatty acids (SFA) $39.30-52.30 \%$, monounsaturated fatty acids (MUFA) $8.62-14.52 \%$, and polyunsaturated fatty acids (PUFA) $34.61-51.88 \%$. The most abundant of PUFA observed was C22:6 (docosahexaenoic acid; DHA) (14.23 - 18.87\%), C20:5 (eicosapentaenoic acid; EPA) (7.28 - 15.76\%), C20:4 (arachidonic acid, AA) (3.17 - 13.68\%), and C18:2 (linoleic acid) 5.59-9.50\%.

For the case of saturated fatty acids, C16:0, C18:0 and C14:0 were found to be the most predominant ones for all types of fish studied. The same trend was observed by Viswanathannair and Gopakumar (1978) and Belling et al. (1997). Lobb and Chow (2000) have also reported that the most abundant of saturated fatty acids in fish oil is C16:0. Palmitic acid was reported to be abundant since it is a key

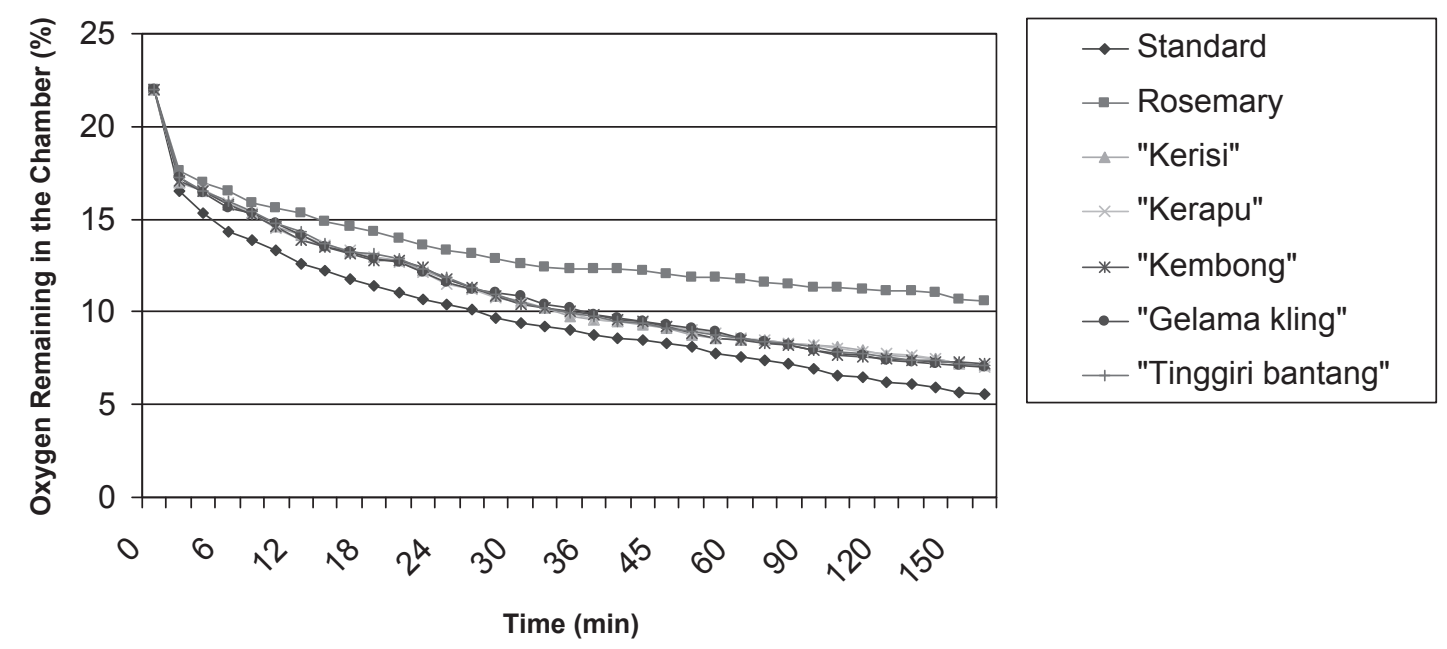

Fig. 1. Percentage oxygen consumption by fish oil samples and rosemary extract in a linoleic emulsion system. For the experimental details, see Materials and Methods. 
Table 1. Changes in fatty acid composition of fish caught in Langkawi Island coastal area, Malaysia, during storage ${ }^{1}$.

\begin{tabular}{|c|c|c|c|c|c|c|c|c|c|c|c|c|c|c|c|}
\hline \multirow{3}{*}{ Fatty acids } & \multicolumn{15}{|c|}{ Local and scientific names } \\
\hline & \multicolumn{3}{|c|}{$\begin{array}{c}\text { "Kerisi" } \\
\text { Scomberomorus commersoni }\end{array}$} & \multicolumn{3}{|c|}{$\begin{array}{c}\text { "Kerapu" } \\
\text { Cynoglossus lingua }\end{array}$} & \multicolumn{3}{|c|}{$\begin{array}{c}\text { "Kembong" } \\
\text { Psettodes crumei }\end{array}$} & \multicolumn{3}{|c|}{$\begin{array}{c}\text { "Gelama kling" } \\
\text { Pristipomodes typus }\end{array}$} & \multicolumn{3}{|c|}{$\begin{array}{l}\text { "Tinggiri batang" } \\
\text { Scolidon sorrakowah }\end{array}$} \\
\hline & Fresh & $-4^{\circ} \mathrm{C}$ & $-27^{\circ} \mathrm{C}$ & Fresh & $-4^{\circ} \mathrm{C}$ & $-27^{\circ} \mathrm{C}$ & Fresh & $-4^{\circ} \mathrm{C}$ & $-27^{\circ} \mathrm{C}$ & Fresh & $-4^{\circ} \mathrm{C}$ & $-27^{\circ} \mathrm{C}$ & Fresh & $-4^{\circ} \mathrm{C}$ & $-27^{\circ} \mathrm{C}$ \\
\hline \multicolumn{16}{|c|}{ Saturated fatty acids (\%) } \\
\hline C10: 0 & 0.14 & nd & nd & 0.06 & nd & nd & 0.03 & nd & nd & 0.03 & nd & nd & 0.11 & nd & 0.10 \\
\hline C14: 0 & 2.78 & 3.11 & 3.00 & 5.90 & 6.50 & 6.40 & 11.35 & 12.30 & 12.10 & 2.67 & 3.10 & 2.80 & 3.00 & 3.15 & 3.10 \\
\hline C15: 0 & 0.99 & 1.30 & 1.11 & 2.04 & 2.80 & 2.38 & 0.75 & 0.90 & 0.88 & 0.95 & 1.00 & 1.10 & 2.24 & 2.25 & 2.10 \\
\hline C16: 0 & 28.07 & 30.33 & 29.57 & 31.07 & 32.56 & 31.90 & 18.83 & 20.06 & 19.85 & 32.65 & 34.68 & 33.62 & 20.31 & 23.00 & 22.26 \\
\hline C17: 0 & 1.86 & 1.92 & 2.10 & 2.11 & 2.56 & 2.15 & 1.04 & 2.10 & 2.00 & 2.03 & 2.44 & 2.50 & 2.59 & 3.10 & 3.00 \\
\hline C18: 0 & 11.77 & 12.47 & 12.25 & 10.71 & 11.80 & 11.42 & 7.73 & 8.40 & 7.80 & 10.88 & 11.20 & 11.00 & 10.39 & 11.70 & 11.20 \\
\hline C20:0 & 0.94 & 0.8 & 0.90 & 0.41 & 0.56 & 0.47 & 0.61 & 0.60 & 0.58 & 1.34 & 1.40 & 1.40 & 0.65 & 1.00 & 0.85 \\
\hline Total & 46.55 & 49.93 & 48.93 & 52.30 & 56.78 & 54.72 & 40.34 & 44.36 & 43.21 & 50.55 & 53.82 & 52.42 & 39.90 & 44.20 & 42.61 \\
\hline \multicolumn{16}{|c|}{ Monounsaturated fatty acids (\%) } \\
\hline C18:1 n-9 & 13.13 & 12.72 & 12.72 & 11.04 & 9.60 & 10.11 & 8.29 & 8.10 & 8.00 & 7.03 & 6.58 & 6.90 & 7.15 & 6.80 & 6.90 \\
\hline C18:1 n-13 & 0.55 & 0.4 & 0.56 & 0.85 & 0.67 & 0.66 & 0.51 & 0.30 & 0.10 & 0.76 & 0.75 & 0.70 & 0.56 & 0.45 & 0.50 \\
\hline C20:1 n-9 & 0.84 & 0.68 & 0.75 & 0.78 & 0.65 & 0.65 & 1.17 & 1.10 & 1.00 & 0.94 & 0.80 & 0.90 & 0.81 & 0.71 & 0.80 \\
\hline $\mathrm{C} 20: 1 \mathrm{n}-13$ & nd & nd & nd & nd & nd & nd & nd & nd & nd & nd & nd & nd & 0.10 & 0.10 & 0.05 \\
\hline Total & 14.52 & 13.80 & 14.03 & 12.67 & 10.92 & 11.42 & 9.97 & 9.50 & 9.10 & 8.73 & 8.13 & 8.50 & 8.62 & 8.06 & 8.25 \\
\hline \multicolumn{16}{|c|}{ Polyunsaturated fatty acids (\%) } \\
\hline C18: 3 n-3 & 0.56 & 0.28 & 0.33 & 0.78 & 0.75 & 0.70 & 0.57 & 0.50 & 0.50 & 0.30 & 0.30 & 0.30 & 0.89 & 0.62 & 0.79 \\
\hline C18: $2 n-6$ & 5.59 & 5.52 & 5.40 & 6.21 & 5.70 & 5.60 & 9.50 & 8.90 & 9.25 & 8.92 & 8.20 & 8.50 & 5.66 & 4.22 & 5.10 \\
\hline $\mathrm{C} 20: 3 \mathrm{n}-3$ & 0.52 & 0.29 & 0.25 & 1.79 & 1.50 & 1.50 & 0.53 & 0.50 & 0.50 & 0.48 & 0.33 & 0.35 & 9.32 & 8.90 & 8.80 \\
\hline C20: 4 n-6: AA & 4.47 & 3.28 & 4.05 & 3.17 & 2.86 & 3.10 & 4.07 & 4.10 & 4.00 & 3.78 & 3.50 & 3.65 & 13.68 & 12.88 & 13.10 \\
\hline C20: 5 n-3: EPA & 9.64 & 8.80 & 9.25 & 8.43 & 8.10 & 8.40 & 15.76 & 14.55 & 15.28 & 10.19 & 9.80 & 10.00 & 7.28 & 7.05 & 7.15 \\
\hline C22: 6 n-3: DHA & 17.70 & 17.12 & 17.60 & 14.23 & 12.45 & 13.56 & 18.87 & 17.25 & 17.30 & 16.71 & 14.95 & 15.40 & 15.05 & 13.96 & 14.02 \\
\hline Total & 38.48 & 35.29 & 36.88 & 34.61 & 31.36 & 32.86 & 49.29 & 45.80 & 46.83 & 40.38 & 37.08 & 38.20 & 51.88 & 47.63 & 48.96 \\
\hline
\end{tabular}

${ }^{1}$ Storage conditions; fresh (no storage), -4 and $-27^{\circ} \mathrm{C}$ for 3 weeks; $n d=$ not detected

metabolite in fish and its level is not influenced by the diet (Ackman and Eaton, (1966).

Fish oil, containing high level of polyunsaturated fatty acids, is very labile to hydrolytic spoilage and especially oxidative deterioration at a varying velocity, strongly depending on storage conditions and fatty acid profile.

As shown in table 6, during storage, for both conditions of storage, SFA of all types of fish slightly increased, while MUFA and PUFA decreased. Storage at $-27^{\circ} \mathrm{C}$ was found to be slightly better in retaining the fatty acid compositions in all fish species studied.

For "kerisi" oil, for example, SFA increased from $46.55 \%$ to $48.93 \%$ when stored at $-27^{\circ} \mathrm{C}$ and to $49.93 \%$ at $-4^{\circ} \mathrm{C}$ for 3 weeks, while it's MUFA decreased from $14.52 \%$ to $14.03 \%$ at $-27^{\circ} \mathrm{C}$ and to 13.80 at $-4^{\circ} \mathrm{C}$. The PUFA contents of this oil decreased from $38.48 \%$ to $36.88 \%$ when stored at $-27^{\circ} \mathrm{C}$ and to $35.29 \%$ at $-4^{\circ} \mathrm{C}$. The oils derived from other fish species in this study had also similar stability pattern to that of "kerisi" oil during their 3-weeks storage.

Peroxide, anisidine, and iodine values Peroxide value $(\mathrm{PV})$ is a measure of the amount of peroxides formed in fats and oils through autoxidation and oxidation processes. Indirectly, it is a measure of the degree of initial oxidation of fats and oils. Table 2 shows that for all types of fish, no peroxide value was detected. After 3 weeks of storage at $4^{\circ} \mathrm{C}$, the PV of "kerapu" increased up to $2.65 \mathrm{meq} \mathrm{O}_{2} / \mathrm{kg}$ oil to become the species with the highest increment in the value. This was followed by "gembong", "gelama kling" and "tinggiri batang" with $2.11 \mathrm{meq} \mathrm{O}_{2} / \mathrm{kg}$ oil, and "kerisi" with $1.84 \mathrm{meq}$ $\mathrm{O}_{2} / \mathrm{kg}$ oil, respectively.

The PVs of samples stored at $-27^{\circ} \mathrm{C}$ were much lower compared to the values of the $4^{\circ} \mathrm{C}$ storage counterparts. For the $-27^{\circ} \mathrm{C}$ storage, the PV of most samples were still nondetectable after 1 week. At this point, only oil samples extracted from "kerapu" and "kembong" showed a PV content, with both fish species containing a very low PV of 0.05 meq $\mathrm{O}_{2} / \mathrm{kg}$ oil. For all samples, it is shown that there was a slight increase in the PV until the end of the storage period. After 3 weeks of storage, the PVs of all samples ranged from 0.70-0.76 meq $\mathrm{O}_{2} / \mathrm{kg}$ oil. However, results showed that no significant difference among all types of oil sample after the 3-week storage.

The low increase in peroxide values observed in this study was similar to several previous reports on fish oil quality by other researchers. It has been reported that PV of sardine oil stored at $-20^{\circ} \mathrm{C}$ increased from 4.12 to 18.6 meq oxygen/kg during frozen storage for 150 days (Verma et al., 1995). In another study, PV of whole fish of whiting (Merluccius mediterraneus) and horse mackerel (Trachurus trachurus) stored at $-18^{\circ} \mathrm{C}$ for one year showed an increase from 3.46 and 8.46 to 28.3 and 24.8 meq oxygen $/ \mathrm{kg}$, respectively (Simeonidou et al., 1997). Karacham and Boran (1996) 
Table 2. Changes in peroxide value (meq $\mathrm{O}_{2} / \mathrm{kg}$ oil) of fish oil stored at two different temperatures.

\begin{tabular}{|c|c|c|c|c|c|}
\hline \multirow{2}{*}{ Local Name } & \multirow{2}{*}{ Scientific Name } & \multicolumn{4}{|c|}{ Weeks of Storage } \\
\hline & & 0 & 1 & 2 & 3 \\
\hline \multicolumn{6}{|l|}{$\operatorname{At~} 4^{\circ} \mathrm{C}$} \\
\hline Kerisi & Scomberomorus commersoni & ND & $0.05^{\mathrm{aA}}$ & $0.38^{\mathrm{aB}}$ & $1.84^{\mathrm{aC}}$ \\
\hline Kerapu & Cynoglossus lingua & ND & $0.05^{\mathrm{aA}}$ & $1.30^{\mathrm{cB}}$ & $2.65^{\mathrm{cC}}$ \\
\hline Kembong & Psettodes crumei & ND & $0.11^{\mathrm{bA}}$ & $0.49^{\mathrm{bB}}$ & $2.11^{\mathrm{bC}}$ \\
\hline Gelama kling & Pristipomodes typus & ND & $0.11^{\mathrm{bA}}$ & $0.49^{\mathrm{bB}}$ & $2.11^{\mathrm{bC}}$ \\
\hline Tinggiri batang & Scolidon sorrakowah & ND & $0.11^{\mathrm{bA}}$ & $1.35^{\mathrm{cB}}$ & $2.11^{\mathrm{bC}}$ \\
\hline \multicolumn{6}{|l|}{ At $-27^{\circ} \mathrm{C}$} \\
\hline Kerisi & Scomberomorus commersoni & ND & ND & $0.11^{\mathrm{aA}}$ & $0.76^{\mathrm{aB}}$ \\
\hline Kerapu & Cynoglossus lingua & ND & $0.05^{\mathrm{aA}}$ & $0.22^{\mathrm{bB}}$ & $0.76^{\mathrm{aC}}$ \\
\hline Kembong & Psettodes crumei & ND & $0.05^{\mathrm{aA}}$ & $0.49^{\mathrm{cA}}$ & $0.70^{\mathrm{aA}}$ \\
\hline Gelama kling & Pristipomodes typus & ND & ND & $0.11^{\mathrm{aA}}$ & $0.76^{\mathrm{aB}}$ \\
\hline Tinggiri batang & Scolidon sorrakowah & ND & ND & $0.11^{\mathrm{aA}}$ & $0.70^{\mathrm{aB}}$ \\
\hline
\end{tabular}

Table 3. Changes in anisidine value of fish oil stored at two different temperatures.

\begin{tabular}{|c|c|c|c|c|c|}
\hline \multirow{2}{*}{ Local Name } & \multirow{2}{*}{ Scientific Name } & \multicolumn{4}{|c|}{ Weeks of Storage } \\
\hline & & 0 & 1 & 2 & 3 \\
\hline \multicolumn{6}{|l|}{ At $4^{\circ} \mathrm{C}$} \\
\hline Kerisi & Scomberomorus commersoni & $0.20^{\mathrm{aA}}$ & $5.28^{\mathrm{bB}}$ & $6.02^{\mathrm{aB}}$ & $11.38^{\mathrm{cC}}$ \\
\hline Kerapu & Cynoglossus lingua & $0.26^{\mathrm{aA}}$ & $4.27^{\mathrm{aB}}$ & $8.38^{\mathrm{bC}}$ & $9.68^{\mathrm{abC}}$ \\
\hline Kembong & Psettodes crumei & $0.69^{\mathrm{bA}}$ & $5.54^{\mathrm{bB}}$ & $6.31^{\mathrm{aB}}$ & $7.60^{\mathrm{aC}}$ \\
\hline Gelama kling & Pristipomodes typus & $0.16^{\mathrm{aA}}$ & $5.60^{\mathrm{bB}}$ & $6.34^{\mathrm{aB}}$ & $8.00^{\mathrm{abC}}$ \\
\hline Tinggiri batang & Scolidon sorrakowah & $0.20^{\mathrm{aA}}$ & $5.54^{\mathrm{bB}}$ & $6.30^{\mathrm{aB}}$ & $7.80^{\mathrm{aC}}$ \\
\hline \multicolumn{6}{|l|}{$A t-27^{\circ} \mathrm{C}$} \\
\hline Kerisi & Scomberomorus commersoni & $0.20^{\mathrm{aA}}$ & $2.34^{\mathrm{aB}}$ & $5.28^{\mathrm{bC}}$ & $6.31^{\mathrm{aC}}$ \\
\hline Kerapu & Cynoglossus lingua & $0.26^{\mathrm{aA}}$ & $2.40^{\mathrm{abB}}$ & $4.27^{\mathrm{aB}}$ & $7.20^{\mathrm{bC}}$ \\
\hline Kembong & Psettodes crumei & $0.69^{\mathrm{bA}}$ & $2.67^{\mathrm{bB}}$ & $5.54^{\mathrm{bC}}$ & $7.70^{\mathrm{bC}}$ \\
\hline Gelama kling & Pristipomodes typus & $0.16^{\mathrm{aA}}$ & $2.14^{\mathrm{aB}}$ & $5.08^{\mathrm{bC}}$ & $6.02^{\mathrm{aC}}$ \\
\hline Tinggiri batang & Scolidon sorrakowah & $0.20^{\mathrm{aA}}$ & $2.46^{\mathrm{abB}}$ & $5.40^{\mathrm{bC}}$ & $6.34^{\mathrm{aC}}$ \\
\hline
\end{tabular}

Mean of three replicates

${ }^{\mathrm{a}-\mathrm{b}}$ Means within a column with different letters are significantly different $(P<0.05)$

${ }^{\mathrm{A}-\mathrm{C}}$ Means within a row with different letters are significantly different $(P<0.05)$

have reported that PVs of whole and gutted anchovy, stored at $-18^{\circ} \mathrm{C}$ for 3 months, increased from 1.8 to 8.2 meq oxy$\mathrm{gen} / \mathrm{kg}$. Another report by Boran et al. (2006) indicated that raw garfish oil stored at 4 and $-18^{\circ} \mathrm{C}$ for 5 months increased from 3.65 to $10.60 \mathrm{meq}$ oxygen $/ \mathrm{kg}$ and from 3.65 to 5.90 meq oxygen $/ \mathrm{kg}$, respectively. Let et al. (2005) reported that the storage temperature, in the range of $2-9^{\circ} \mathrm{C}$, had small but important, effects on the oxidation of the fish oil enriched milk emulsion.

Young (1986) reported that PV of crude fish oil was lower than $20 \mathrm{meq}$ oxygen $/ \mathrm{kg}$. According to Huss (1988), the acceptability limit for PV of crude fish oil is 7-8 meq oxygen $/ \mathrm{kg}$. Low levels of PV exhibited of all samples examined in this study showed that they were within the limit and of good quality for consumption.

Results from Table 2 also indicated that duration of storage had a significant $(P<0.05)$ effect on peroxide values of all samples. The peroxides values increased with increased time of storage until week 3. Augustin and Berry (1983a) reported that hydroperoxides, the primary products of oxidation, degrade to form secondary products of which aldehydic components are measured by the anisidine value $(\mathrm{AnV})$ test. This test has an enhanced sensitivity for unsaturated aldehydes, especially 2,4-dienals, but does not measure the ketonic secondary products of oxidation (Augustin and Berry 1983b). In this study, there was a marked increase in anisidine values $(\mathrm{AnVs})$ for all samples after week 1 (Table 3). The AnVs for all types of fish oil stored at $-27^{\circ} \mathrm{C}$ increased from $0.16-0.69$ 
at week 0 to $4.27-5.60$ at week 1 , while the oils stored at $4^{\circ} \mathrm{C}$ increased to 2.14-2.67 after one week of storage.

After three weeks of storage, the AnVs ranged from 6.02 to 7.70 for samples stored at $-27^{\circ} \mathrm{C}$, and from $7.60-11.38$ for oil samples stored at $4^{\circ} \mathrm{C}$. It is clearly seen that during storage at $-27^{\circ} \mathrm{C}$, the oil derived from "kembong" had the highest increment in the AnV, whereas the "kerisi" oil was found to be the highest among the samples stored at $4^{\circ} \mathrm{C}$. It is interesting to see the changes of AnVs of the "kerisi" oil during the storage at the two different temperatures. While it was found to be the most degradable oil at $4^{\circ} \mathrm{C}$, the oil was one of the most stable ones when stored at $-27^{\circ} \mathrm{C}$. At this temperature, there was no significant $(P>0.005)$ difference between AnVs of "kerisi", "gelama kling", and "tinggiri batang" oils.

Iodine value (IV) is a measure of the total number of unsaturated double bonds present in an oil. The differences in iodine values of the oil during storage are also indicative of the increased rate of oxidation. A significant change in iodine value can be observed when there is an excessive deterioration of the oil (Augustin and Berry, 1983a). Similar to $\mathrm{PV}$ and $\mathrm{AnV}$, in this study, the storage time gave a significant effect on iodine value (Table 4).

The IVs of fresh oil samples ranged from 178.17 ("kembong") to $190.37 \mathrm{~g} \mathrm{I} / 100 \mathrm{~g}$ oil ("gelama kling"). It is clearly seen that there was no significant difference $(P>0.05)$ between the values of "kerisi", "kembong" and "kerapu". The value of "kerapu" was also found to be significantly similar $(P<0.05)$ to that of "tinggiri batang". However, after week 3 , the PV of "kerapu" oil was significantly higher $(P<0.05)$ than the PVs of the oils of "kerapu" and "kembong" when they were stored at $4^{\circ} \mathrm{C}$.
After week 3, the IVs of oils stored at $4^{\circ} \mathrm{C}$ ranged from 168.22 to $186.25^{\circ} \mathrm{C} \mathrm{g} \mathrm{I}_{2} / 100 \mathrm{~g}$ oil, whereas the oils stored at $-27^{\circ} \mathrm{C}$ were from 173.50 to $186.10 \mathrm{~g} \mathrm{I}_{2} / 100 \mathrm{~g}$ oil. At $4^{\circ} \mathrm{C}$ storage, "kerisi" oil was found to be the most unstable one, where its IV decreased from 178.71 to 168.22 , followed by "kembong" oil with the decreased IV from 178.17 to 169.00 $\mathrm{g} \mathrm{I}_{2} / 100 \mathrm{~g}$ oil. The IVs of other oils decreased slightly from 182.51 to 175.20 ("kerapu”), from 190.37 to 186.25 ("gelama kling") and from 184.88 to $180.50 \mathrm{~g} \mathrm{I}_{2} / 100 \mathrm{~g}$ ("tinggiri batang").

In terms of stability, results showed that in general, the changes in IVs of all oils stored $-27^{\circ} \mathrm{C}$ were better than those from $4^{\circ} \mathrm{C}$ storage. After 3 weeks of storage at $-27^{\circ} \mathrm{C}$, the percentage of loss of unsaturation of "kerisi" oil was $2.41 \%$, much better than a loss of $5.86 \%$ when stored at $4^{\circ} \mathrm{C}$. The percentage of loss of unsaturation for "kerapu" was $1.79 \%$ (compared to $4 \%$ at $4{ }^{\circ} \mathrm{C}$ ), whereas the loss for "kembong" oil was $2.62 \%\left(5.15 \%\right.$ at $\left.4^{\circ} \mathrm{C}\right)$.

However, the unsaturation loss of the other two oils stored at $-27^{\circ} \mathrm{C}$ were relatively comparable to the loss at the $4^{\circ} \mathrm{C}$ storage. The oil extracted from "gelama kling" stored at $-27^{\circ} \mathrm{C}$ had the unsaturation loss of $2.13 \%\left(2.16 \%\right.$ at $\left.4{ }^{\circ} \mathrm{C}\right)$, whereas the unsaturation loss of "tinggiri batang" oil was $2.29 \%\left(2.34 \%\right.$ at $\left.4^{\circ} \mathrm{C}\right)$. A study by Boran et al. (2006) reported that the changes in IV contents of garfish oil during storage at 4 and $-18^{\circ} \mathrm{C}$ for 5 months were very low, 8.5 and $3.3 \%$, respectively.

Thiobarbituric acid and acid values Changes in thiobarbituric acid (TBA) values of oils derived from 5 different fish species are given in Table 5. The TBA values of fresh oils ranged from 1.18-1.36 mg MA/kg; however, no significant difference $(P>0.05)$ among these TBA values was

Table 4. Changes in iodine value $\left(\mathrm{g} \mathrm{I}_{2} / 100 \mathrm{~g}\right.$ oil) of fish oil stored at two different temperatures.

\begin{tabular}{|c|c|c|c|c|c|}
\hline \multirow{2}{*}{ Local Name } & \multirow{2}{*}{ Scientific Name } & \multicolumn{4}{|c|}{ Weeks of Storage } \\
\hline & & 0 & 1 & 2 & 3 \\
\hline \multicolumn{6}{|l|}{$\operatorname{At~}^{\circ}{ }^{\circ} \mathrm{C}$} \\
\hline Kerisi & Scomberomorus commersoni & $178.71^{\mathrm{aB}}$ & $175.20^{\mathrm{aB}}$ & $170.10^{\mathrm{aA}}$ & $168.22^{\mathrm{aA}}$ \\
\hline Kerapu & Cynoglossus lingua & $182.51^{\mathrm{abB}}$ & $180.56^{\mathrm{bB}}$ & $178.60^{\mathrm{bAB}}$ & $175.20^{\mathrm{bA}}$ \\
\hline Kembong & Psettodes crumei & $178.17^{\mathrm{aC}}$ & $175.15^{\mathrm{aB}}$ & $171.80^{\mathrm{aA}}$ & $169.00^{\mathrm{aA}}$ \\
\hline Gelama kling & Pristipomodes typus & $190.37^{\mathrm{cB}}$ & $188.75^{\mathrm{cAB}}$ & $188.00^{\mathrm{cAB}}$ & $186.25^{\mathrm{dA}}$ \\
\hline Tinggiri batang & Scolidon sorrakowah & $184.88^{\mathrm{bB}}$ & $183.15^{\mathrm{bAB}}$ & $182.20^{\mathrm{bA}}$ & $180.50^{\mathrm{cA}}$ \\
\hline \multicolumn{6}{|l|}{$A t-27^{\circ} \mathrm{C}$} \\
\hline Kerisi & Scomberomorus commersoni & $178.71^{\mathrm{aB}}$ & $177.50^{\mathrm{aAB}}$ & $176.80^{\mathrm{aAB}}$ & $174.40^{\mathrm{aA}}$ \\
\hline Kerapu & Cynoglossus lingua & $182.51^{\mathrm{abB}}$ & $181.90^{\mathrm{abB}}$ & $180.20^{\mathrm{bA}}$ & $179.25^{\mathrm{bA}}$ \\
\hline Kembong & Psettodes crumei & $178.17^{\mathrm{aB}}$ & $177.60^{\mathrm{aB}}$ & $175.60^{\mathrm{aA}}$ & $173.50^{\mathrm{aA}}$ \\
\hline Gelama kling & Pristipomodes typus & $190.37^{\mathrm{cB}}$ & $189.15^{\mathrm{cB}}$ & $188.30^{\mathrm{cB}}$ & $186.30^{\mathrm{cA}}$ \\
\hline Tinggiri batang & Scolidon sorrakowah & $184.88^{\mathrm{bB}}$ & $183.50^{\mathrm{bB}}$ & $181.25^{\mathrm{bA}}$ & $180.65^{\mathrm{bA}}$ \\
\hline
\end{tabular}


Table 5. Changes in thiobarbituric acid value $(\mathrm{mg} \mathrm{MA} / \mathrm{kg})$ of fish oil stored at two different temperatures.

\begin{tabular}{llcccc}
\hline \multirow{2}{*}{ Local Name } & \multicolumn{1}{c}{ Scientific Name } & \multicolumn{3}{c}{ Weeks of Storage } \\
\cline { 3 - 5 }${\text { At } \mathbf{4}^{\circ} \boldsymbol{C}}$ & & 0 & 1 & 2 & 3 \\
Kerisi & Scomberomorus commersoni & $1.21^{\mathrm{aA}}$ & $3.51^{\mathrm{bB}}$ & $4.10^{\mathrm{bcC}}$ & $5.26^{\mathrm{bD}}$ \\
Kerapu & Cynoglossus lingua & $1.36^{\mathrm{aA}}$ & $2.85^{\mathrm{aB}}$ & $4.48^{\mathrm{cC}}$ & $6.21^{\mathrm{cD}}$ \\
Kembong & Psettodes crumei & $1.26^{\mathrm{aA}}$ & $3.20^{\mathrm{bB}}$ & $4.05^{\mathrm{bB}}$ & $4.96^{\mathrm{bC}}$ \\
Gelama kling & Pristipomodes typus & $1.18^{\mathrm{aA}}$ & $2.96^{\mathrm{aB}}$ & $3.55^{\mathrm{aB}}$ & $5.15^{\mathrm{bC}}$ \\
Tinggiri batang & Scolidon sorrakowah & $1.20^{\mathrm{aA}}$ & $3.05^{\mathrm{ab}}$ & $3.95^{\mathrm{bB}}$ & $4.20^{\mathrm{aB}}$ \\
At $\mathbf{- 2 7}^{\circ} \boldsymbol{C}$ & & & & & \\
Kerisi & Scomberomorus commersoni & $1.21^{\mathrm{aA}}$ & $2.34^{\mathrm{aAB}}$ & $2.68^{\mathrm{abB}}$ & $3.71^{\mathrm{cC}}$ \\
Kerapu & Cynoglossus lingua & $1.36^{\mathrm{aA}}$ & $1.95^{\mathrm{aA}}$ & $2.55^{\mathrm{abA}}$ & $3.80^{\mathrm{cB}}$ \\
Kembong & Psettodes crumei & $1.26^{\mathrm{aA}}$ & $2.00^{\mathrm{aA}}$ & $2.34^{\mathrm{aAB}}$ & $2.55^{\mathrm{aB}}$ \\
Gelama kling & Pristipomodes typus & $1.18^{\mathrm{aA}}$ & $2.45^{\mathrm{aB}}$ & $2.90^{\mathrm{bB}}$ & $3.60^{\mathrm{bcC}}$ \\
Tinggiri batang & Scolidon sorrakowah & $1.20^{\mathrm{aA}}$ & $2.46^{\mathrm{aB}}$ & $2.85^{\mathrm{bB}}$ & $3.10^{\mathrm{bB}}$ \\
\hline
\end{tabular}

Mean of three replicates

${ }^{a-c}$ Means within a column with different letters are significantly different $(P<0.05)$

${ }^{\text {A-D }}$ Means within a row with different letters are significantly different $(P<0.05)$

Table 6. Changes in acid value $(\mathrm{mg} \mathrm{KOH} / \mathrm{g})$ of fish oil stored at two different temperatures.

\begin{tabular}{|c|c|c|c|c|c|}
\hline \multirow{2}{*}{ Local Name } & \multirow{2}{*}{ Scientific Name } & \multicolumn{4}{|c|}{ Weeks of Storage } \\
\hline & & 0 & 1 & 2 & 3 \\
\hline \multicolumn{6}{|l|}{$\operatorname{At} 4^{\circ} \mathrm{C}$} \\
\hline Kerisi & Scomberomorus commersoni & $1.11^{\mathrm{aA}}$ & $1.61^{\mathrm{bcB}}$ & $3.10^{\mathrm{cC}}$ & $4.46^{\mathrm{abD}}$ \\
\hline Kerapu & Cynoglossus lingua & $1.02^{\mathrm{aA}}$ & $1.80^{\mathrm{cB}}$ & $2.88^{\mathrm{aC}}$ & $5.41^{\mathrm{cD}}$ \\
\hline Kembong & Psettodes crumei & $1.00^{\mathrm{aA}}$ & $1.40^{\mathrm{bA}}$ & $3.04^{\mathrm{bcB}}$ & $4.86^{\mathrm{bC}}$ \\
\hline Gelama kling & Pristipomodes typus & $0.90^{\mathrm{aA}}$ & $1.36^{\mathrm{bA}}$ & $2.95^{\mathrm{aB}}$ & $4.68^{\mathrm{bC}}$ \\
\hline Tinggiri batang & Scolidon sorrakowah & $0.85^{\mathrm{aA}}$ & $1.05^{\mathrm{abA}}$ & $2.75^{\mathrm{aB}}$ & $4.15^{\mathrm{aC}}$ \\
\hline \multicolumn{6}{|l|}{$A t-27^{\circ} \mathrm{C}$} \\
\hline Kerisi & Scomberomorus commersoni & $1.11^{\mathrm{aA}}$ & $1.24^{\mathrm{aA}}$ & $2.58^{\mathrm{bB}}$ & $2.88^{\mathrm{bB}}$ \\
\hline Kerapu & Cynoglossus lingua & $1.02^{\mathrm{aA}}$ & $1.75^{\mathrm{bB}}$ & $2.02^{\mathrm{abB}}$ & $2.46^{\mathrm{aC}}$ \\
\hline Kembong & Psettodes crumei & $1.00^{\mathrm{aA}}$ & $1.44^{\mathrm{aA}}$ & $2.14^{\mathrm{aAB}}$ & $2.45^{\mathrm{aC}}$ \\
\hline Gelama kling & Pristipomodes typus & $0.09^{\mathrm{aA}}$ & $1.38^{\mathrm{aA}}$ & $2.00^{\mathrm{aB}}$ & $2.55^{\mathrm{aC}}$ \\
\hline Tinggiri batang & Scolidon sorrakowah & $0.85^{\mathrm{aA}}$ & $1.24^{\mathrm{aA}}$ & $1.85^{\mathrm{aB}}$ & $2.90^{\mathrm{bC}}$ \\
\hline
\end{tabular}

Mean of three replicates

${ }^{\mathrm{a}-\mathrm{c}}$ Means within a column with different letters are significantly different $(P<0.05)$

${ }^{\text {A-D }}$ Means within a row with different letters are significantly different $(P<0.05)$

observed. During 3 weeks of storage, results showed that there were gradual increases of TBA values of all types of. After 3 weeks, the TBA values ranged from 4.20 to $6.21 \mathrm{mg}$ $\mathrm{MA} / \mathrm{kg}$ at $4^{\circ} \mathrm{C}$ and from 2.55 to $3.80 \mathrm{mg} \mathrm{MA} / \mathrm{kg}$ at $-27^{\circ} \mathrm{C}$. At $4{ }^{\circ} \mathrm{C}$, the greatest increase was shown by "kerapu" oil (3.57\%), followed by "gelama kling" and "kerisi" oils with 3.36 and $3.34 \%$, respectively. The increase in TBA values for the oils from "kembong" and "tinggiri batang" were 2.94 and $2.50 \%$, respectively. At $-27^{\circ} \mathrm{C}$, "kerisi" oil showed the greatest increase in TBA values $(2.07 \%)$. The increase for "gelama kling" oil was $2.05 \%$, "kerapu" (1.79\%) and "tinggiri batang" (1.58\%). The lowest increase for this storage condition was exhibited by "kembong" oil with $1.02 \%$.

Similar to TBA values, acid value (AV) also gradually in- creased with the increased storage time for both storage temperature (Table 6). This findings are in line with the report of Boran et al. (2006), indicating that TBA and AV values of fish oil had slightly decrease with the increased duration of storage. The biggest increase in AV was seen in "kerapu" (from 1.02 to $5.41 \mathrm{mg} \mathrm{KOH} / \mathrm{g}$ ) for the storage at $4^{\circ} \mathrm{C}$ and in "tinggiri batang" (from 0.85 to $2.90 \mathrm{mg} \mathrm{KOH} / \mathrm{g}$ ) for samples stored $-27^{\circ} \mathrm{C}$. Increase in AV is generally associated with lipase activity originating from microorganisms or biological tissue. The acceptable limit for $\mathrm{AV}$ is reported to be $7-8 \mathrm{mg}$ $\mathrm{KOH} / \mathrm{g}$ (Bimbo, 1998). Our results showed that this limit has not been reached by any oil sample examined until the end of 3-week storage period. 


\section{Conclusion}

The effect of storage temperatures on oil quality of various fish species caught in Pulau Tuba, near Langkawi Island, in Malaysia was examined. Results showed that in general, stability of oils stored at $-27^{\circ} \mathrm{C}$ was better than that of oils stored at $4^{\circ} \mathrm{C}$. IV of oils decreased during storage, while other parameters increased. However, the rate of quality deterioration of oil samples was relatively low, meaning that both storage temperatures might be used for storage purposes of fish oil. The existence of initial antioxidants in the oil samples might also contribute to high stability of samples during storage.

\section{References}

Ackman, R.G. and Eaton, C.A. (1966). Some commercial Atlantic herring oils: Fatty acid composition. J. Fish Res., 23, 911-917.

Augustin, M.A. and Berry, S.K. (1983a). Effectiveness of antioxidants in refined, bleached and deodorized palm olein. J. Am. Oil Chem. Soc., 60, 105-107.

Augustin, M.A. and Berry, S.K. (1983b). Efficacy of the antioxidants BHA and BHT in palm olein during heating and frying. $J$. Am. Oil Chem. Soc., 60, 1520-1524.

Belling, G.B., Abbey, M., Campbell, J.H. and Campebell, G.R. (1997). Lipid content and fatty acid composition of 11 species of Queensland (Australia) fish. Lipids, 32, 621-626.

Boran, G., Karacam, H. and Boran, M. (2006). Changes in the quality of fish oils due to storage temperature and time. Food Chem., 98, 693-698.

Bimbo, A.P. (1998). Guidelines for characterizing food-grade fish oils. Inform., 9(5), Hertfordshire, UK.

Connor, W.E. (2000). Importance of n-3 fatty acids in health and diseases. Am J. Clin. Nutr., 71, 171S-175S.

Folch, J., Lee, M. and Stanley, G.H. (1957). A simple method for the isolation and purification of total lipids from animal tissues. $J$. Biol. Chem., 226, 497-496.

Huss, H.H. (1988). Fresh Fish Quality and Quality Changes. Rome: FAO.

IUPAC. (1987). Standard Methods for Analysis of Oils, fats and Derivatives, $7^{\text {th }}$ ed. IUPAC App. Chem. Commission on Oils, Fats and Derivatives (Paquot, C. and A. Hautfenne, eds.). Oxford: Blackwell Scientific Publications.
Karacam, H. and Boran, M. (1996). Quality changes in frozen whole and gutted anchovies during storage at $-18^{\circ} \mathrm{C}$. Int. J. Food Sci. Tech., 31, 527-531.

Let, M.B., Jacobsen, C. and Meyer, A.S. (2005). Sensory stability and oxidation of fish oil enriched milk storage temperature and oil quality. Int. Dairy J., 15, 173-182.

Lingnert, H., Vallentin, K. and Eriksson, C.E. (1979). Measurement of antioxidative effect of model system. J. Food Proc. Preserv., 3, 87-103.

Lobb, K. and Chow, C.K. (2000). Fatty acids in foods and their health implications (2nd Ed.). New York: Marcel Dekker, Inc.

Marchioli, R. (2001). Efficacy of n-3 polyunsaturated fatty acids after myocardinal infaction: Results of gissi-prevenzione trial. Lipids., 36, S119-S126.

McGookin, B.J. and Augustin, M.A. (1991). Antioxidant Activity of Casein and Maillard Reaction Products from Casein-Sugar Mixtures. J. Dairy Res., 58, 313-320.

PORIM. (1995). PORIM Test Methods. Bangi, Selangor: Palm Oil Research Institute of Malaysia, Ministry of Primary Industries, Malaysia.

Rafflenbeul, W. (2001). Fish for a healthy heart. Eur. J. Lipid Sci. Tech., 103, 315-317.

Simeonidou, S., Govaris, A. and Vareltzis, K. (1997). Effects of frozen storage on the quality of whole fish and fillets of horse mackerel (Trachurus trachurus) and Mediterranian hake (Merluccius mediterraneus). Z. Lebensm Unters Forsch A., 204, 405-410.

Steel, R.G.D. and Torrie, J.H. (1980). Principles and Procedures of Statistic. New York: McGraw Hill.

Verma, J.K., Srikar, L.N., Sudhakara, N.S. and Sarma, J. (1995). Effects of frozen storage on lipid freshness parameters and some functional properties of oil of dardine (Sardinella longiceps) Mince. Food Res. Int., 28, 87-90.

Viswanathannair, P.G. and Gopakumar, K. (1978). Fatty acid compositions of 15 species of fish from tropical waters. J. Food Sci., 43, 1162-1164.

Wijewickreme, A.N. and Kitts, D.D. (1997). Influence of Reaction Conditions on the Oxidative Behavior of Model Maillard Reaction Products. J. Agric. Food Chem., 45, 4571-4576.

Young, F.V.K. (1986). The chemical and physical properties of crude fish oils for refiners and hydrogenators. Fish Oil Bull., 18, Liverpool, UK. 